\title{
Editorial: What is in a Name? A Proposal to Use Geomycosis Instead of White Nose Syndrome (WNS) to Describe Bat Infection Caused by Geomyces Destructans
}

\author{
Vishnu Chaturvedi $\cdot$ Sudha Chaturvedi
}

Received: 30 November 2010/Accepted: 30 November 2010/Published online: 5 January 2011

(C) Springer Science+Business Media B.V. 2010

In 2006, a mysterious condition was first observed in hibernating bats near Albany, NY, US [1]. The affected animals and carcasses displayed a prominent cotton-like growth around the nostrils, which came to be colloquially termed White Nose Syndrome (WNS). Subsequent studies indicated that the cottony appearance was due to fungal growth. The extensive fungal colonization of bat skin and hair, characteristic histopathological appearance, and exclusive presence of a specific fungal DNA in the animals' tissues led to the discovery of the causal agent-a newly described species called Geomyces destructans [2-6]. Subsequent studies revealed that this condition has caused the deaths of nearly a million bats in the Northeast and it has rapidly spread to other parts of the country [7]. Unfortunately, the prognosis for bats remains poor at present. The US Fish and Wildlife Service has decided to impose extreme measures, such as barring human access to the caves and the mines where bats live, in an attempt to stop further spread of this disease (http:// www.fws.gov/whitenosesyndrome/pdf/NWRS_WNS_ Guidance_Final1.pdf). Recently, G. destructans growth

V. Chaturvedi $(\bowtie) \cdot$ S. Chaturvedi

Mycology Laboratory, Wadsworth Center, New York

State Department of Health and Department of

Biomedical Sciences, University at Albany School of

Public Health, 120 New Scotland Ave., Albany, NY

12208, USA

e-mail: vishnu@wadsworth.org

S. Chaturvedi

e-mail: schaturv@wadsworth.org was reported on bats from many European countries, but the associated morbidity or mortality seen in the US bats was absent from the European animals [8, 9]. Thus, G. destructans causes both colonization and invasive infections in Chiroptera. The underlying mechanisms causing such a wide spectrum of hostpathogen interactions still remain unknown.

Bats afflicted with WNS have many symptoms, such as, emaciation, epidermal erosion and ulcers, and extensive wing damage $[4,10]$. Accordingly, this disease can be confirmed by the morphological appearance of the fungus on any part of the body, histopathology of affected tissues with demonstration of hyphae-conidia, or demonstration of $G$. destructans by PCR-nucleotide sequencing [3, 4, 6, 11]. Thus, it is reasonable to conclude that WNS is neither an exclusive presentation nor an all-encompassing description of $G$. destructans infections in bats. The continued use of this terminology to describe bat disease carries the risk of undue focus on one symptom of what is likely to be a complex hostpathogen interaction.

In the fungal kingdom, Geomyces destructans has the closest affinity with Geomyces pannorum, which is widely distributed from the Arctic and the Antarctic to temperate climate zones in cave soil and other substrates [12-15]. The two species can be distinguished by their characteristic conidia and subtle differences in the nucleotide sequences of the ribosomal DNA [5, 16]. Geomyces pannorum is a rare pathogen of humans and animals. It has been 


\section{GEOMYCOSIS}

\section{Geomyces destructans Geomyces pannorum}
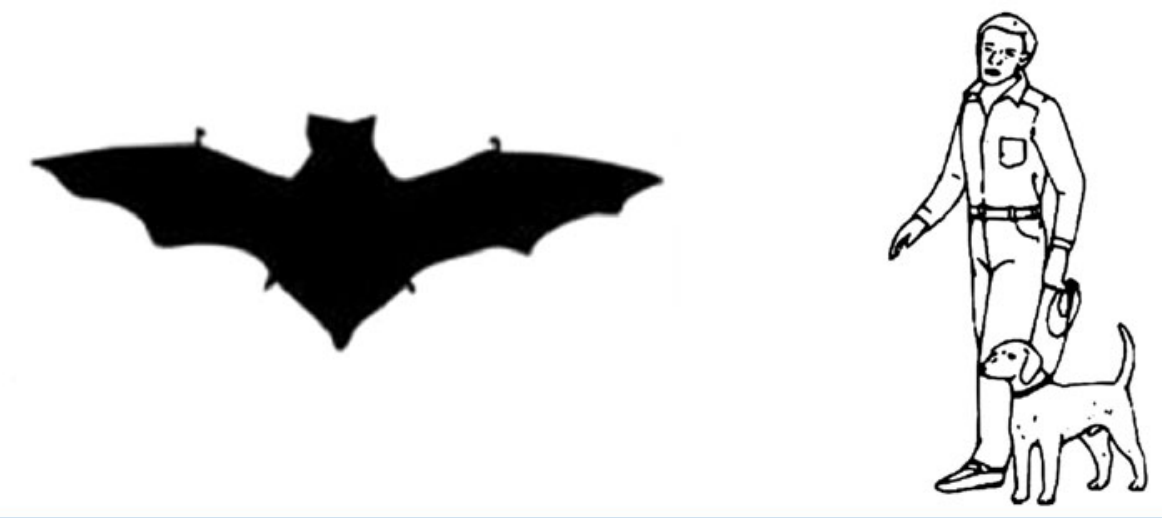

Fig. 1

documented as a cause of skin and nail infections in humans, and bone infections in dogs [16-20]. Thus, two closely related psychrophilic ("cold-loving") fungi are now documented as pathogens of humans and animals. It is conventional in medical and veterinary mycology to name diseases by combining the specific epithet of the etiologic agent and the suffix -cosis (singular, [Gr.], disease, morbid state, abnormal increase) or -coses (plural). Thus, candidiasis encompasses a wide variety of illnesses caused by Candida species, and geotrichosis refers to infections caused by Geotrichum species. As explained in Fig. 1, we propose that the term "geomycosis" be adopted to describe infections caused by both G. destructans and G. pannorum. The adoption of this term for bat infections would properly describe a disease that has been described so far in peer-reviewed literature by a prominent symptom (WNS). An associated benefit of using an accurate descriptive term would be to recognize that the current diagnostic criteria for $G$. destructans disease in bats might include, exceed, or even exclude WNS. Geomycosis also establishes a logical link between $G$. destructans and G. pannorum, which could promote meaningful comparisons between the two to understand their pathogenic mechanisms for mammalian hosts. Finally, an appropriate disease name would elicit increased attention from the wider scientific community outside of the wildlife experts. Ideally, such attention would prompt future studies on outstanding questions, such as, how psychrophilic or psychotrophic fungi acquire pathogenic traits, how these attributes are maintained and enhanced, and what causes the emergence of these particular human and animal diseases.

\section{References}

1. Kelly T. Bats perish, and no one knows why. The New York Times; 2008 Sect. 1.

2. Blehert DS, Hicks AC, Behr M, Meteyer CU, BerlowskiZier BM, Buckles EL, et al. Bat white-nose syndrome: an emerging fungal pathogen? Science. 2009;323(5911):227.

3. Chaturvedi V, Springer DJ, Behr MJ, Ramani R, Li X, Peck MK, et al. Morphological and molecular characterizations of psychrophilic fungus Geomyces destructans from New York bats with White Nose Syndrome (WNS). PLoS One. 2010;5(5):e10783.

4. Meteyer CU, Buckles EL, Blehert DS, Hicks AC, Green DE, Shearn-Bochsler V, et al. Histopathologic criteria to confirm white-nose syndrome in bats. J Vet Diagn Invest. 2009;21(4):411-4.

5. Gargas A, Trest MT, Christensen M, Volk TJ, Blehert DS. Geomyces destructans sp.nov. associated with bat whitenose syndrome. Mycotaxon. 2009;108:147-54.

6. Lorch JM, Gargas A, Meteyer CU, Berlowski-Zier BM, Green DE, Shearn-Bochsler V, et al. Rapid polymerase 
chain reaction diagnosis of white-nose syndrome in bats. J Vet Diagn Invest. 2010;22(2):224-30.

7. Frick WF, Pollock JF, Hicks AC, Langwig KE, Reynolds DS, Turner GG, et al. An emerging disease causes regional population collapse of a common North American bat species. Science. 2010;329(5992):679-82.

8. Puechmaille SJ, Verdeyroux P, Fuller H, Gouilh MA, Bekaert M, Teeling EC. White-nose syndrome fungus (Geomyces destructans) in bat, France. Emerg Infect Dis. 2010;16(2):290-3.

9. Wibbelt G, Kurth A, Hellmann D, Weishaar M, Barlow A, Veith $\mathrm{M}$, et al. White-nose syndrome fungus (Geomyces destructans) in bats, Europe. Emerg Infect Dis. 2010;16(8): 1237-43.

10. Cryan PM, Meteyer CU, Boyles JG, Blehert DS. Wing pathology of white-nose syndrome in bats suggests lifethreatening disruption of physiology. BMC Biol. 2010; 8(1): 135 .

11. Courtin F, Stone WB, Risatti G, Gilbert K, Van Kruiningen HJ. Pathologic findings and liver elements in hibernating bats with White-Nose Syndrome. Vet Pathol; 2010. Epub 0300985809358614 [pii].

12. Hughes KA, Lawley B, Newsham KK. Solar UV-B Radiation inhibits the growth of Antarctic terrestrial fungi. Appl Environ Microbiol. 2003;69(3):1488-91.

13. Kochkina GA, Ivanushkina NE, Akimov VN, Gilichinskii DA, Ozerskaia SM. Halo- and psychrotolerant Geomyces fungi from arctic cryopegs and marine deposits. Mikrobiologiia. 2007;76(1):39-47.

14. Marshall WA. Aerial transport of keratinaceous substrate and distribution of the fungus Geomyces pannorum in Antarctic soils. Microb Ecol. 1998;36(2):212-9.

15. Bastian F, Jurado V, Novakova A, Alabouvette C, SaizJimenez C. The microbiology of Lascaux Cave. Microbiology. 2010;156(3):644-52.

16. de Hoog GS, Guarro J, Gene J, Figueras. Atlas of clinical fungi. 3rd ed., Pilot Version ed. Utrecht: CBS/Universitat Rovira i Virgli; 2009.

17. Christen-Zaech S, Patel S, Mancini AJ. Recurrent cutaneous Geomyces pannorum infection in three brothers with ichthyosis. J Am Acad Dermatol. 2008;58(5 Suppl 1):S112-3.

18. Gianni C, Caretta G, Romano C. Skin infection due to Geomyces pannorum var. pannorum. Mycoses. 2003;46(910):430-2.

19. Zelenkova H. Geomyces pannorum as a possible causative agent of dermatomycosis and onychomycosis in two patients. Acta Dermatovenerol Croat. 2006;14(1):21-5.

20. Erne JB, Walker MC, Strik N, Alleman AR. Systemic infection with Geomyces organisms in a dog with lytic bone lesions. J Am Vet Med Assoc. 2007;230(4):537-40. 